\title{
The Impact On Trust And Online Buying Decisions Through Information Quality, Celebrity Endorser And Price Perception At Instagrams In Surabaya
}

\author{
Abdul Halik \\ Lecturer at Faculty of Economics and Business, \\ August 17, 1945 Surabaya University.
}

\begin{abstract}
the development of e-commerce today is not only selling and buying products online but also people are always using the internet for convenience in their lives. Activities in e-commerce include the process of providing products, sales, services, shipping and payment systems for consumers with the support of a network of business partners throughout the world. The internet for business people can be used to market products with low advertising costs. Instagram is one of the internet sites in Indonesia that implements the e-commerce system in the world. This website, Instagram, is visited by many people from Indonesia and abroad because it is easy to access. Instagram provides a business profile account that has its advantages for business people. Instagram is a social media based on mobile applications, so it is easy to use wherever you want to access your account without using a computer. Using the Instagram application there are no special requirements for selling or shopping on the Instagram application, but you need to register an account on Instagram, then you can take advantage of all the features offered by this application. The aim of making it easier to buy and sell people online and get efficiency in online shopping. The research objective is to find out the significances of trust, celebrity endorser, and price perception on online purchasing decisions via Instagram. There are 200 online respondents in Surabaya to get these data. This type of research is a quantitative research method with an explanatory method to get the answers. Each variable can be known to contribute to shaping consumers to make online buying decisions. The tool used to analyze this research is SEM version of AMOS 24. Research with information quality, celebrity endorser and price perception influences trust as an intervening variable of purchasing decisions. These mean the exogenous variables used in this study affect consumer confidence. The information presented is clear, the role of the maximum endorser and the perceived price perception can be trusted, then online shoppers will immediately decide to buy the items needed. While the direct effect of the exogenous variable to the endogenous variable is only the price perception variable which has a positive and significant effect. The information quality and celebrity endorsers have a positive but not significant effect, meaning that consumers who buy only see offers of prices related to discounts, free shipping, and guarantees provided by online sellers. The information quality in the online purchasing process makes consumers adequate trusted the information that is displayed on Instagram. The role of celebrity endorsers in advertising products or services is desirable to motivate prospective online buyers. The endorsers can increase the enthusiasm to buy items that are promoted on Instagram. It can influence consumers buying decisions. Moreover, confidence variables can help remind consumers of complete information, famous endorsers and price perceptions that include price discounts, guarantees on products purchased until they are in good condition and according to buyer expectations. Online businesses must take all risks because there is no guarantee that the products received are the same as the picture displayed. Information that is easily accessible and discounted prices that are interested and gives reasonable guarantees to consumers. Trust will grow well if supported by clear information, there will be an online purchasing decision. The existence of an online business can provide convenience to human needs and job creation to reduce unemployment in Indonesia, especially the young generation.

Keywords: Information quality, celebrity endorser, price perception, trust, and buying decision..
\end{abstract}




\section{INTRODUCTION}

Technological developments can be felt in various fields namely transportation, electronic communication, and business in cyberspace. E-commerce is not only selling and buying goods online but is proceeding in various sectors of public interest on this earth. Start with the process of marketing, selling, shipping and paying consumers with the support of a network of business partners throughout the world. The existence of an e-commerce system depends on internet resources and other information technologies that support each process that the user follows. The reason for developing business by using the internet is very potential throughout the world which is always increasing. The total population of Indonesian people in early 2019 was 268 million. Even the number of social media users in Indonesia reaches 150 million people, a very rapid increase because almost the world's population is social media literate.

Instagram is a social media that is widely used by internet users in Indonesia. Instagram uses photo and video sharing applications then users take photos or videos, apply digital filters and share them with social networking services like Instagram. On April 9, 2012, Instagram was taken by Facebook with a value of $\$ 1$ billion in cash and shares of a technology start-up company called Burbn, inc. Instagram is ranked 3rd most widely used internet application users in the world. Instagram won the Shorty Award in 2012. Millennials do the most dominant shopping, which is $50 \%$ with ages $25-34$ years. Most online shopping consumers by gender are $65 \%$ women. An online shop on Instagram provides contacts that can be contacted to interact via WhatsApp, another line.

People's lifestyles also change because of the presence of technology with the presence of gadgets so that they do activities in cyberspace such as online shopping or online shopping. The internet has a strategic role to get to know the virtual world because it can be accessed by anyone. The global internet system is the entire computer network that is connected to the Internet Protocol Suite (TCP / IP) to serve users throughout the world. Internet users in Indonesia continue to increase and the results of a survey from the Association of Indonesian Internet Service Providers (APJII) said the number of internet users in Indonesia in 2018 reached 171.17 people or 64.08 percent of the population in Indonesia.

Purchases made by consumers with e-commerce are influenced by various factors, including; the level of risk that must be borne by consumers is the impact of online marketing on the products /services offered will affect consumer confidence in certain online stores. Consumers prefer shopping online than traditional shopping because online shopping is more convenient and has its own pleasure for consumers to get goods and services at lower prices. Before deciding to buy there are factors to consider regarding trust in online transactions that must have certainty and clear information. There is mutual trust between sellers and buyers and consumer confidence in e-commerce is an important factor in buying and selling online.

The act of buying online does not meet the online shop seller so it takes the trust of the buyer to the seller. If it is not based on trust between seller and buyer, the transaction will never occur even if the product is of high quality and affordable prices. Trust must be built regularly by online shop sellers so that buyers are confident in products sold in cyberspace. Shopping habits have shifted to online, because technology and the internet go together, so people can get things easily without leaving the house. Humans rarely interact only with the closest person. For that, online shop sellers must increase trust if they want the business to remain sustainable. 
Information quality is consumers' perception of the information quality about goods or services available on the website. The higher the information quality provided to online buyers, the higher the number of people making online purchasing decisions for certain products. Online business people should spread quality information if they want to increase their trust in the online business. No matter how good the information is available, but it needs to be supported by the ease of being able to access information and easy access and an attractive virtual store.

Easy information, attractive prices, and the role of celebrity endorsers influences for making online purchasing decisions for consumers. Celebrity endorser is a well-known actor, artist, and athlete who can be used as an admirer to deliver advertisement messages that attract attention, in order to influence target consumers. Celebrity endorsers reinforce so that the goods or services to be sold can be used by people who follow in his footsteps. The message received by someone will benefit those who will buy goods or services because of the influence of the celebrity endorser.

Prices can influence consumers' decision to make a purchase and encourage purchasing decisions. Price of the main element for consumers before buying goods or services. The price of one element of the marketing mix that generates company revenue, while other elements will incur costs such as the process of making products, distributing products and the presence of promotional activities. Many consumers shop online looking for cashback and hunt for discounts. Online shopping consumers are pampered with various price discounts and free shipping. Consumers like to find simple and safe ways of payment, for example, cash on delivery or pay after the goods arrive. A person must have adequate knowledge about basic online shopping because for the following (1) price is not negotiable (2) shipping costs according to location conditions, (3) understanding the availability of goods purchased, (4) return policy if a problem occurs (5) Comprehensive procedures for goods and services.

Online shopping is an electronic trading activity for consumers to directly buy products or services from sellers via the internet with a web browser. The payment system has been determined and the product will be sent via the product delivery service according to agreed terms. The offer of goods is relatively competitive, so the products sold can be responded to by buyers. Through the online shop, buyers can see several products offered on the web that are promoted by sellers in their May stores. Online Shop Trend seems to be increasing because it is more practical and more comfortable, but must maintain the trust of consumers continuously and the availability of quality products and services. Online shop does spoil its buyers, but there is a risk that must be borne by consumers if the goods are not sent on time, the quality of the goods is not appropriate and the goods can not be available, even there is a fake online shop under the guise. For that, consumers must be careful in conducting transactions in online business, so as not to cause losses..

\section{LITERATURE REVIEW.}

\section{Marketing.}

According to Kotler and Keller (2018)[1], marketing is an organizational function and a series of processes to create, communicate and provide value to customers to manage customer relations in ways that benefit the organization and the parties concerned with the organization. Marketing is a whole system of business activities aimed at planning, pricing, promoting and distributing goods and services that satisfy the needs of both existing and potential buyers (Dharmmesta, 2008)[2]. According to Sudaryono (2016)[3], marketing is a business process that seeks to align the human, financial and physical resources of an organization with the needs and desires of consumers in the context of competitive strategies. Marketing activities 
provide the best and satisfaction to consumers. In line with that, it is necessary to have an understanding between producers and consumers because it must create a continuous transaction. The world of online business is now very popular and promises to benefit the parties involved in online business. Competitive strategies must be run by online businesses such as varied discounts, free shipping and guarantee of goods to their destinations. In short, marketing is the process of business organization functions in conducting relationships to meet the needs and desires of consumers that are mutually beneficial to the parties involved in the business.

\section{Marketing Mix.}

Kotler (2007)[4] says that the marketing mix is a combination of the four core variables of the marketing system are the product, price, distribution, and promotion. According to Sofjan Assauri (2014)[5], marketing mix is a combination of variables or activities that are the core of the marketing system, which variables can be controlled by marketing to influence the reactions of buyers or consumers. While Buchari Alma (2014)[6], the marketing mix is a strategy of combining marketing activities, in order to create the maximum combination so that the most satisfying results will appear. Determine the price policy in the form of discounts, free shipping makes online buyers interested. Doing the right promotion so that consumers quickly understand the goods or services sold online will make buyers curious about the convenience provided by shopping online. However, cooperation with the shipping agency is needed, so that it can reach the buyer quickly. Maintaining trust with stakeholders is necessary to achieve success in online business.

The conclusion, the marketing mix is a collection of variables that companies can use to influence consumers or customers. The marketing mix is to strengthen and improve the response for marketing elements so that a transaction process occurs between supply and demand according to company goals and mutual benefit. The use of the right marketing mix, will increase sales volume and maintain the company's sustainability.

\section{Online Marketing.}

According to (2007)[4] Online Marketing is marketing done through an interactive online computer system by connecting consumers and sellers electronically. While online business services offer online marketing and information services to buyers to pay dues. Online marketing is the work of companies to communicate, promote and sell goods and services via the internet. Whereas Boone and Kurtz (2005)[7] say online marketing is one component of ecommerce and is in the interests of marketers, namely the process of making products, distributing, promoting, and determining the prices of goods and services on the internet market or through other digital tools. Online marketing is a marketing strategy developed based on the times and advances in human technology that are utilized to market a product or service through the internet network. Digital marketing is all efforts made to market a product /service using electronic media.

The purpose of online marketing is to sell goods and services by advertising through the internet. Online marketing can be an effective way to identify target markets or find the wants and needs of market segments. The use of the internet and digital technology is related to achieving market objectives and supporting modern marketing concepts. The benefits of online marketing for sellers/business owners benefit a lot from online marketing. Social media is very effective because in the social media users in the country of Indonesia is huge population, in order to increase opportunities. Online marketing does not always provide fast and instant 
results, but it still requires a process, but indeed the time required is shorter than the traditional way.

The conclusion, Online marketing is the process of business transactions with marketing activities through products/services using internet media that are mutually beneficial between sellers and buyers. The development of online shopping must be followed by the provision of quality products and fast delivery. Forms of cooperation between online businesses are needed so that business activities can be beneficial for the parties involved.

\section{Information Quality.}

For online shopping, we should present information relating to products and services available in online shopping. Useful and relevant information to predict the quality and usefulness of products/services. Information on products and services must always be updated to satisfy the needs of online shoppers. Surely online sellers can help buyers make decisions, to be consistent and easy to understand so that profitable transactions occur. Online businesses must display complete and easily accessible information, so that consumers are more interested in the offer made, to speed up buying decisions from consumers. Information quality is relevant, timeliness, safe and is presented with good information design on a website (Liu and Arnett, 2000)[8]. The quality of information needed by the online business world, because consumers will believe that the information presented is not in doubt and helps in making decisions. The quality of information can also be seen by the potential to produce infinite information both within and outside the organization (Barnes and Vidgen, 2003)[9]. The ability to provide quality information depends greatly on available technological factors such as the internet.

The higher the information quality provided to online shoppers, the higher the number of people buying the product online (Park, CH and Kim, YG (2003)[10], while the quality of information is consumers' perceptions of the information quality about goods and services available on a website. Online business people try to spread quality information, so people will increase their trust in online business, a good information but supported by the ease of being able to get information and easy access into attractive cyberspace stores. Support from technology elements is needed to facilitate business activities. on line.

The conclusion, information quality is the process of providing accurate and easily accessible information needed by the online business world so that consumers believe that the information displayed does not make buyers doubt in making decisions. Ease of online shopping, consumers need quality information so that motivation to buy increases.

\section{Celebrity Endorser}

An endorse is a form of support and recommendations given to someone for a brand or product, the support of someone's public figure. Endorse is a form of promotion that utilizes celebrities or professionals to convey the good about a brand, product, or service. Endorse activities in Indonesia are not new promotions but have been going on for a long time and products that use famous artists or figures to increase sales volume. Celebrity Endorsement is the support of well-known artists, athletes, or public figures used for success in their respective fields of supported fields. According to Shimp (2007)[11] said that a celebrity endorser is a person, be it an actor, artist or athlete known to the public and become an idol, because of achievements in a field and used in conveying advertising messages that are intended to attract attention to influence the target consumers. Celebrity endorsers provide more reinforcement on the products/services sold, that they use. The message someone receives will benefit consumers who will buy the product/service. 
Celebrity endorsers have to do with honesty, trust, and integrity of the endorser, eligibility to be trusted in endorsers depends on consumers' perceptions and motivation of endorsers. In choosing a public figure, it must be following the needs of the product/service to be sold, because there is a strong urge for consumers to buy if there is conformity with the endorser. Celebrity endorsers have several elements including expertise, credibility, testimony, and attractiveness. Celebrities can be used as a quick tool to represent targeted market segments (Royan, 2005)[12]. According to Handi Chandra (2008)[13] said that celebrity endorser is promoting a product with the artist as the advertiser figure.

The conclusion is that celebrity endorser is a product/service promotion mix activity by utilizing a public figure that conveys promotional messages according to the intended segment. Consumers who already believe will make a purchase even by shopping online.

\section{Price Perception.}

Price perception is the way consumers perceive a certain price whether high, low or reasonable which has a strong influence on consumer purchase intentions and purchase satisfaction (Sciffman and Kanuk, 2010)[14]. The price element in a company determines the growth of the business that is done, the more careful in determining the price, then it benefits consumers too. The price information is related to price perception that needs to be fully understood and gives meaning to consumers. Price is the amount of money that consumers must pay to obtain products in the form of product/services referred to as the party offering. The nominal form of money from the price to be paid has been through an agreement between the two parties that have an interest. Price perception is the tendency of buyers to use prices to assess the suitability of the product value. An assessment of the benefits of a product is associated with the high cost of an individual item is not the same, because it depends on the perception of the person behind the environment and the condition of the individual itself.

According to Campbell in Cockril and Goode (2010)[15] states the perception of prices is a psychological factor in various aspects that have an important influence on consumer reactions to prices. For this reason, price perception is the reason for someone to make a buying decision. Whereas Lee and Lawson-Body (2011)[16] say that price perception is the assessment of consumers and associated emotional forms about whether prices offered by sellers and prices compared to other parties make sense can be accepted or justified. Price perception is an approach to explain the impact of prices on a product or a high involvement purchasing situation. Consumer knowledge to compare prices offered by other brands in the same type of product. Competitor prices provide an overview of the company, in order to determine pricing policies, so they can be accepted by consumers.

In summary, price perception is the result of consumer thinking to compare prices that are considered expensive, cheap and fair so that they can provide benefits and benefits. Potential consumers will see from a variety of perspectives, to get goods that fit their needs with adequate purchasing power. Online businesses rely more on discounts to reach large numbers of consumers, with the addition of free shipping. Determine the price in online business must be careful to win the competition.

\section{Trust.}

Trust in the seller is the ability of the seller to provide services to the buyer, the seller's willingness to provide benefits to both parties and the behavior of the seller in running the business. Lim et al. (2001)[17] state consumer confidence in internet shopping as consumers' willingness to expose themselves to possible losses experienced during internet shopping 
transactions, based on the expectation that sellers promise transactions that will satisfy consumers and be able to send goods or services that have been promised. The buyer's trust in the online buying and selling site lies in the popularity of the site used, the more popular the site, the buyer will feel more confident to shop online. Online trading sites are common and consumers are sometimes unsure of the seller and the outcome of the transaction. Trust is a crucial role in fostering relationships, especially in service businesses that are full of uncertainty, risk and lack of information between interconnected parties (Halik, 2017)[18]. The level of trust is the most important aspect of building a commitment and promise that needs to be realized so that all objectives are achieved. It can be concluded that trust is a vital aspect in overcoming diverse criticisms and difficulties in online business and is a valuable asset in developing a long-term interaction in the organization.

\section{Buying Decision}

Kotler \& Armstrong (2014)[19] said that purchasing decisions are part of consumer behavior, namely the study of how individuals, groups and organizations choose, buy, use, and how goods, services, ideas or experiences to satisfy their needs and desires. While Machfoedz (2013)[20], states that the purchase decision is a process of valuation and selection of various alternatives following certain interests and determine a choice that is considered the most profitable. Activities in purchasing decisions are not separate from consumer behavior so that each consumer has different habits in buying decisions.

Before deciding to buy various aspects become considerations such as trust, online transactions must have certainty and asymmetrical information, so consumers are confident. For this reason, there must be mutual trust between the seller and the buyer. Consumer confidence in e-commerce is one of the main aspects of buying and selling online. The decision to buy online does not meet with the seller in online shopping, so it takes the trust of the buyer to the seller. According to Mahkota (2014)[21] that trust is a significant factor that influences online purchasing decisions, so consumers who have confidence who make buying and selling transactions online. If it is not based on trust between the seller and the buyer, there will never be a sale and purchase even though quality products at affordable prices. Trust must be built continuously so that consumers believe in products sold in cyberspace. In conclusion, the purchase decision is a process of determining several alternative solutions to problems with adequate knowledge and concrete actions.

\section{Research Design}

\section{RESEARCH METHODS}

Produce good research results, a comprehensive plan is needed. The research design is a plan, conceptual framework of the structure of relations between variables in a research study (Kerlinger, 1990)[22]. Whereas Aaker and Day (2001)[23] say that a detailed plan is used as a guideline for research that leads to the research objectives. The research plan is to explain some influential variables and test hypotheses and conduct explanations on several variables so that the nature of the research is explanatory research.

\section{Population and Sample}

The population is a certain quantity and characteristics that exist in a location. The population to be studied needs to be selected based on the appropriate number of samples in the research to be conducted. The population is someone who does online shopping through Instagram in the city of Surabaya. In this study set a sample of 200 people. Respondents are people chosen according to the guidelines outlined in this study who want to fill out a questionnaire sent online via Instagram and send it back to researchers. This research is the citizens of the Surabaya city who have made online transactions through social media more than five times. 


\section{Sample and measurement techniques.}

This research method using Purposive Sampling is a sampling technique with certain considerations. Researchers used a purposive sampling method by choosing people, according to the needs of respondents and had transactions online through social media, especially Instagram. The measurement scale is to use agreement as a guideline to determine the short length of an interval as a measurement tool and when used in measuring it will produce quantitative data (Sugiyono, 2010)[24]. The measuring tool is a Likert scale to measure the attitudes, opinions, and perceptions of humans or groups of a social phenomenon that is developing at this time.

\section{Data Collection Technique.}

Data collection techniques through the steps of making a questionnaire and circulated to respondents by the objectives of the study. Using primary and secondary data are:

a. Primary data is data obtained directly from respondents and the results of questionnaires filled out by respondents ie people shopping online in the city of Surabaya.

b. Secondary data is already available in a particular institution by the object of research.

\section{Data Analysis Technique}

Multidimensional research is a practical phenomenon that will be examined, with several indicators that are in accordance with the phenomenon that is happening now. The analysis of the research is the answer from the respondents which is inputted into data and then entered into the Structural Equation Modeling (SEM) version AMOS 24 as a tool to answer the selected exogenous and endogenous variables and following the phenomenon.

\section{Profile of respondent}

\section{ANALYSIS RESULTS DATA DESCRIPTION}

Respondents used in this study were 200 respondents and residents residing in the city of Surabaya as shown in the following table. 
Table : 1

Profile respondent

\begin{tabular}{|c|c|c|}
\hline DESCRIPTION & FREQUENCY & $\%$ \\
\hline $\begin{array}{l}\text { Gender: } \\
\circ \quad \text { Man } \\
\circ \text { Women }\end{array}$ & $\begin{array}{c}104 \\
98\end{array}$ & $\begin{array}{l}52 \\
48\end{array}$ \\
\hline Total & 200 & 100 \\
\hline $\begin{array}{l}\text { Age : } \\
\circ \quad 18 \text { years }-28 \text { years } \\
\circ \quad 29 \text { years }-39 \text { years } \\
\circ \quad 40 \text { years }-50 \text { years } \\
\circ \quad \geq 51 \text { years }\end{array}$ & $\begin{array}{l}84 \\
72 \\
32 \\
12 \\
\end{array}$ & $\begin{array}{c}42 \\
36 \\
16 \\
6 \\
\end{array}$ \\
\hline Total & 200 & 100 \\
\hline $\begin{array}{ll}\text { Education : } \\
\circ & <\text { Graduated from Middle school } \\
\circ & \text { Graduated High school } \\
\circ & \text { Graduated Diploma } \\
\circ & \text { Graduated Bachelor } \\
\end{array}$ & $\begin{array}{c}8 \\
66 \\
48 \\
78\end{array}$ & $\begin{array}{c}4 \\
33 \\
24 \\
39\end{array}$ \\
\hline 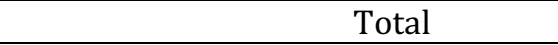 & 200 & 100 \\
\hline $\begin{array}{l}\text { Work : } \\
\circ \text { Civil servant/Army/Police } \\
\circ \text { Entrepreneurship } \\
\circ \text { Private employees } \\
\circ \text { Student } \\
\end{array}$ & $\begin{array}{l}16 \\
84 \\
90 \\
10\end{array}$ & $\begin{array}{c}8 \\
42 \\
45 \\
5\end{array}$ \\
\hline Total & 200 & 100 \\
\hline $\begin{array}{ll}\text { Expenditures : } \\
0 \quad<\text { IDR.1.000.000 } \\
\circ \quad \text { IDR.1.000.000 s/d IDR.5.000.000 } \\
\circ \quad>\text { IDR.5.000.000 }\end{array}$ & $\begin{array}{c}8 \\
60 \\
132\end{array}$ & $\begin{array}{c}4 \\
30 \\
66\end{array}$ \\
\hline Total & 200 & 100 \\
\hline $\begin{array}{l}\text { Buying Frequency: } \\
\circ \quad 1-5 \text { time } \\
\circ \quad 6-10 \text { time } \\
\circ \quad 11-15 \text { time } \\
0 \quad>15 \text { time } \\
\end{array}$ & $\begin{array}{l}24 \\
82 \\
72 \\
22 \\
\end{array}$ & $\begin{array}{l}12 \\
41 \\
36 \\
11 \\
\end{array}$ \\
\hline Total & 200 & 100 \\
\hline
\end{tabular}

\section{Test Validity and Reliability}

\section{Test validity.}

The validity test is to test the statement. Validity test to measure whether the measuring instrument used is valid or invalid. Validity test in this study the authors use SPSS software version 25. Item validity test is a valid statement if it has strong support for the total score. To fulfill the validity requirements, the questions in the research must have a correlation coefficient $(r)>0.30$, and if the correlation between the total score items $<0.30$, then the questions in the questionnaire are declared invalid (Sugiono, 2010)[24]. Test the validity of all items of the indicator meet the validity requirements, because the statement items in the study must have a correlation coefficient $r>0.30$ and if the correlation between total score items 0.30 , then the statement items in the questionnaire declared invalid.

To test the validity of the construct, it is necessary to meet the requirements, first, the loading factor must be significant. For that significant loading factor so the value is still low, then the standardized loading estimate needs to be equal to 0.50 or more, the ideal should be 0.70 (Ghozali; 2017)[25]. The results of the loading factor value of each indicator can confirm the variable properly. Empirical data used is by the framework of the variables used. The cut of value used to test the significant factor weight is loading factor $\geq 0.5$ or critical ratio $>2.0$, because the significant indicator is the dimension of the latent variable formed. 


\section{Test Reliability}

Testing the instrument is done with internal consistency as indicated by the Cronbach Alpha coefficient $>0.6$, then the question can be declared reliable (Nunally) in (Ghazali; 2017)[25]. All indicators of each variable from the results of the Alpha Cronbach coefficient calculation are all indicators above 0.6 , meaning that all the variables used are said to be reliable. The criteria used are if the construct reliability $>0.70$, then it shows good or reliable reliability, while the reliability of $0.60-0.70$ can still be accepted with the condition of the validity of indicators in good capital (Ghozali; 2017)[25]. The result of the reliability value for all constructs is $>0.70$ which means that all indicators of exogenous and endogenous variables are reliable.

\section{A New Optimized Ranking Algorithm}

\section{ANALYSIS OF DATA}

The results of testing using structural equation modeling require several steps. To get fit model results, it is necessary to do modification indices, according to the facilities owned by SEM, because the modification results can be seen in the following figure

Figure: 1

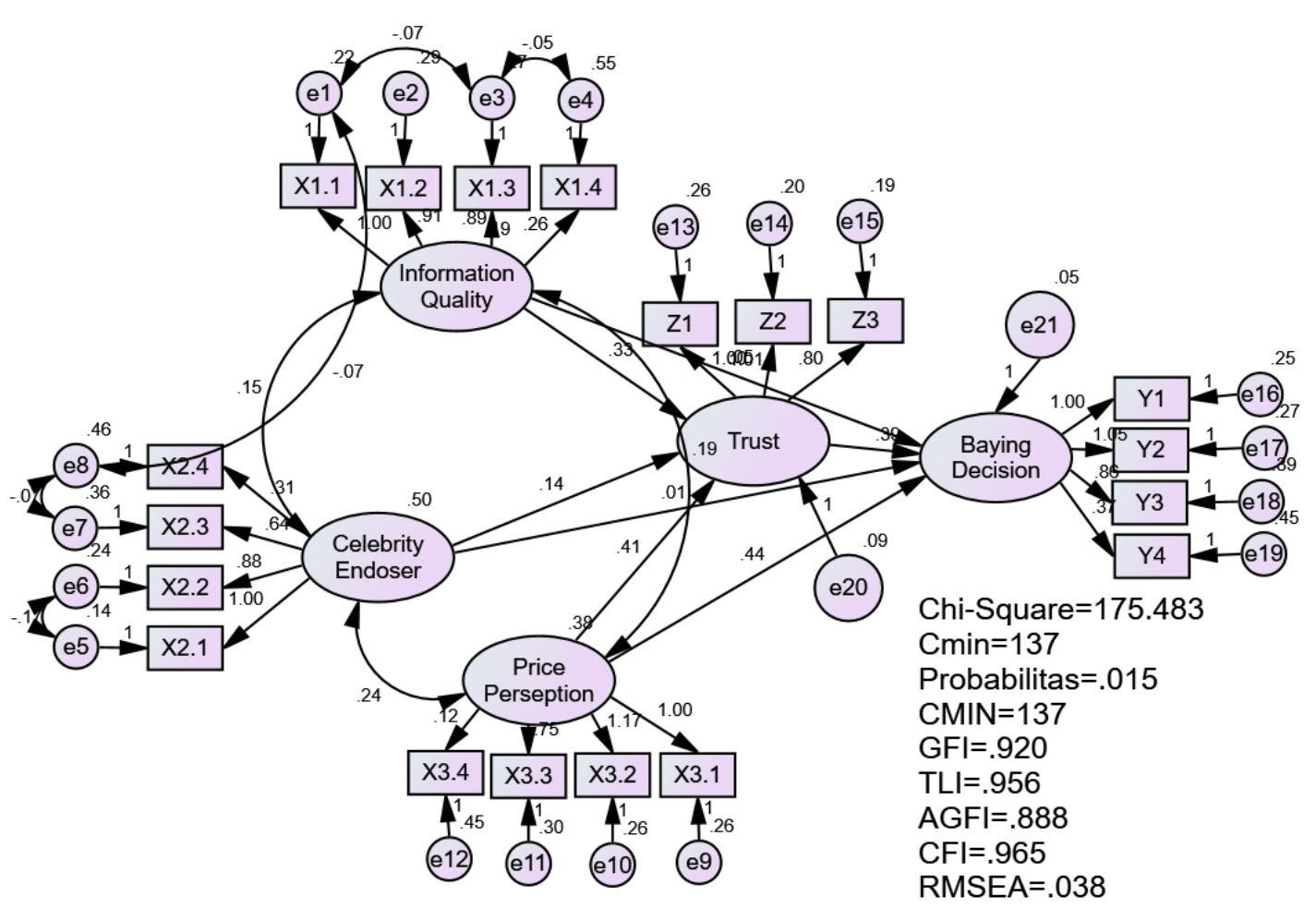

The above model is acceptable, although the results of the evaluation of the Goodness of fit indices criteria all the required criteria have been met and are appropriate and good. To test the hypothesis of a causal relationship between information quality variables, celebrity endorsers, price perceptions of trust and purchasing decisions in the city of Surabaya. The results of the path coefficient of the causal relationship between the variables in this study can be seen in the following Table. 
Table : 2

Path coefficient of relationship between variables.

\begin{tabular}{|l|l|c|c|c|c|}
\hline No & Variable & $\begin{array}{c}\text { Path } \\
\text { coefficient }\end{array}$ & $\begin{array}{c}\text { Critical } \\
\text { Ratio }\end{array}$ & Probability & Information \\
\hline 1. & $\begin{array}{l}\text { Trust 4-- Information } \\
\text { Quality }\end{array}$ & 0,331 & 2,091 & 0,036 & Significant \\
\hline 2. & $\begin{array}{l}\text { Trust 4-· Celebrity } \\
\text { Endoser }\end{array}$ & 0,139 & 2,238 & 0,025 & Significant \\
\hline 3. & $\begin{array}{l}\text { Trust 4-· Price } \\
\text { Perception }\end{array}$ & 0,407 & 3,676 & 0,000 & Significant \\
\hline 4. & $\begin{array}{l}\text { Baying Decision -- } \\
\text { Information Quality }\end{array}$ & 0,050 & 0,341 & 0,733 & Not significant \\
\hline 5. & $\begin{array}{l}\text { Baying Decision 4-- } \\
\text { Celebrity Endoser }\end{array}$ & 0,010 & 0,179 & 0,858 & Not significant \\
\hline 6. & $\begin{array}{l}\text { Baying Decision 4-- Price } \\
\text { Perception }\end{array}$ & 0,444 & 3,557 & 0,000 & Significant \\
\hline 7. & Baying Decision --- Trust & 0,385 & 2,519 & 0,012 & Significant \\
\hline
\end{tabular}

Source: Primary data process.

Analysis using probability values and significant criteria, if $\mathrm{P} \leq 0.05$ then testing using $\mathrm{t}$ table $=$ 1.960, with the following results (1) Information quality has a positive and real impact on trust, (2) Celebrity endorser has a positive and real effect on trust, (3) Price perception has a positive and real influence on trust, (4) Information quality has a positive and unreal effect on buying decisions, (5) Celebrity endorsers influence positively and not real buying decisions, (6) Price perception has a positive effect and real on buying decisions, (7) Trust has a positive and real influence on buying decisions.

Based on the above hypothesis testing, it can be seen that the five hypotheses that were accepted were 5 and two were not accepted, the critical ratio and probability results can be seen as follows :

1) The information quality influences trust. Based on the calculation, significant occurred using the value of $C R=2.091 \geq 1.960$ with $P=0.036 \leq 0.05$. This means that the hypothesis (H-1), the information quality has a positive and real effect on trust. Shows that the information quality presented by online businesses influences buyer confidence. The information available in cyberspace stores is easy to view and gives confidence to buyers. But the information that is informed must exist in the real world so that buyers are not disappointed. The price discount delivered on the web must be kept, not between those listed in the information turned out to be mere fantasy. Business people must reassure them, for example, in cyberspace.

2) Celebrity endorser influences the buyer's trust, from the calculation the results are significant using the value of $C R=2.238 \geq 1.960$, and $P=0.025 \leq 0.05$. This means that the hypothesis (H-2), celebrity endorser has a positive and real influence on trust. Celebrities are more effective than endorsers like company managers. Celebrities who have the same personality with goods, brands, and consumers will have very good credit and have the ability to improve consumer buying decisions and increase profits for sellers. But the celebrity used has an excellent reputation, both in terms of achievement and personality, so that it becomes an example for fans. Online shoppers have high trust in celebrities who are endorsers. Using celebrities is more effective in the short term if the purpose of advertising is to create brand trust in new products. Using celebrities is a choice and not a necessity. Many advertisements that do not use celebrities, still managed to increase purchases on online shopping. The intelligence of online businesses is a key factor in the success of an advertisement on Instagram. 
3) Price perception influences trust, calculation results are significant and CR value = $3.676 \geq 1.960$ with $\mathrm{P}=0.000 \leq 0.05$. For hypothesis $(\mathrm{H}-3)$, price perception has a positive and real impact on trust. The price element in the marketing mix plays an important role, to maintain the sustainability of a business. Online sellers need to be sensitive about changes in the way people shop, which is related to increasingly good information technology. Ease of getting products/services through social media, online sellers must be responsive and respond to needs by determining affordable prices. Price discount policy is a tactic for reaching large numbers of consumers, but it takes time to convince consumers. Trust through information conveyed by online sellers must have accurate and accessible quality information to find out their suitability.

4) The quality of information has a positive influence on purchasing decisions. Based on the calculation the results are insignificant and the value of $\mathrm{CR}=0.341 \leq 1.960$ and $\mathrm{P}=$ $0.733 \geq 0.05$, and for the hypothesis $(\mathrm{H}-4)$ the quality of information has a positive effect, but not significantly on purchasing decisions in online shopping. Perfect value information if possible as a basis for making optimal decisions and trying to avoid events that will bring harm to all parties. Information is only valuable for people who have sufficient knowledge to use as a basis for decisions. For example, consumers already get complete information from online sellers but do not immediately buy goods because they are still trying to find accurate information. For this reason, the information available is trustworthy or not, so consumers do not buy right away. The process of purchasing goods if all information presented in a virtual store can be trusted and convincing for consumers.

5) Celebrity endorsers influence online shopping purchase decisions on Instagram for the citizens of Surabaya, so the calculation results occur insignificantly and the value of $\mathrm{CR}=$ $0.179 \leq 1.960$, and $\mathrm{P}=0.858 \geq 0.05$. Based on the hypothesis $(\mathrm{H}-5)$, celebrity endorser has a positive and not significant effect on purchasing decisions. Companies in the selection of endorsers are expected to be more careful in choosing celebrity endorsers because the costs incurred are indeed baseline. Choosing endorsers who have persuasive power can attract consumers to buy. Sometimes consumers do not consider the endorser but only based on their needs and purchasing power. Celebrities used should be generally well-known and trusted by the public because of their achievements as a public figure. Endorser display on Instagram must be interesting and unique so that consumers immediately respond to offers in the form of products/services that will be sold online via Instagram.

6) The effect of price perception on online purchasing decisions via Instagram in the city of Surabaya, from the calculated results, is significant and the value of CR $=3.557 \geq 1.960$ and $\mathrm{P}=0.000 \leq 0.05$. This means that the hypothesis $(\mathrm{H}-6)$, price perception has a positive and significant influence on purchasing decisions. In online shopping, the main thought is the price offered with the quality of existing products, as well as various risks faced by buyers. Prices can be suitable and often ignore the availability of goods and shipping when the goods will arrive at their destination. Various discounts are offered and the ease of shipping and even free shipping, to encourage consumers to immediately decide to buy via online. The ease of payment and communication to both parties must be continuous so that consumers increase confidence in online shopping.

7) Trust has an influence on online purchasing decisions in the city of Surabaya, with the calculation results showing significant and CR value $=2.519 \geq 1.960$ and $\mathrm{P}=0.012$ s 0.05 . For this reason, hypothesis (H-7), namely trust, has a positive and real influence on purchasing decisions. The element of trust from online sellers and buyers needs to be followed by good service. The diversity of products sold attracts buyers because consumers usually want to shop for goods online in full from just one person. Shipping 
costs become a consideration when shopping online in one place so you can get the goods quickly. Online sellers must choose a shipping partner that is already well-known and trusted because it will increase consumer confidence. Product quality needs to be conveyed to consumers, so they don't feel cheated by the seller. The information presented has good quality, so that they are confident in the virtual world shop so that online businesses will continue to grow in Indonesia.

\section{Interpretation of research results. \\ Information quality influence trust.}

EXPERIMENTS AND ANALYSIS

The information quality in the online business world is crucial for success, accurate and easy information makes consumers interested in getting goods easily. The results of this study indicate that the quality of information has a positive effect on trust, which means that the information distributed requires trust from consumers. Various information from online sellers must be detailed both about the quality of goods, prices of goods and discounts provided, to make consumers interested in shopping online. Information about the ease of transaction needs to be conveyed in communication time so that doubts about online business can be minimized.

The information age is marked by many changes in information technology that is very beneficial to humans. Utilization of internet technology is implemented in the form of ecommerce which is a website that provides online shopping transactions that are growing in Indonesia. Trading is made easier with e-commerce which has a positive impact and increases effectiveness and efficiency in today's business world. Making various businesses can be served by e-commerce that is easy to use to provide accurate information to consumers.

This study aims to determine the effect of information quality on trust that can ultimately make online purchasing decisions. But the decision to buy online is not only based on information quality factors, but there are still other factors that influence such as celebrity endorsers, price perception and other factors. The availability of good information, then consumers will be interested in shopping online and will also provide information to friends about the online shopping experience which turned out to be easier. Delivery of goods is sought as soon as possible to the consumer so that trust is higher and profits from sellers are increasing.

\section{Celebrity endorsers influence trust.}

The endorser is a promotional strategy that many companies do to increase sales of their products. The company pays the person who has a reputation or achievement to be used as an endorser, intending to communicate a message that the company wants to achieve and to provide information about the product itself. Not only communicating the message expected by entrepreneurs but endorsers must have an attractive appearance and good skills so that product success can be achieved. Economic activities can develop over time, now economic activities are more effective through the digital world. All buying and selling transactions are carried out in digital media, now many online stores are loved by the public because they are more efficient and effective. Whereas online stores have more efficient promotional strategies for consumers and produce low cost to introduce their products on social media Instagram.

Celebrities needed are already known to the public, have achievements that have been trusted by the public. If the character chosen does not match the product you want to advertise, then the endorser will not be effective in increasing sales. The influence of celebrity endorsers on products will have a positive impact if carried out on the appropriate market segment so that 
the target product is right for the intended consumer. The appearance of the endorser must be made very attractive on the website so that interested consumers are potentially able to make a purchase. Celebrity endorsers are used by online stores to attract consumers' purchasing power because celebrities are well-known people who have strong characters and values so that promotional strategies using celebrities are very fast to attract the attention of consumers. Business opportunities through online stores are increasingly thriving and it is not only online stores that continue to grow, but online shopping consumers continue to rise. It seems that the online shop business opportunity is wide open including SMEs and Village products. The communication and information network in this world can cover globally, so that people today can interact across countries, cultures and religions. This business field triggers online store managers to compete to provide efficient services in online shopping and marketing strategies that lure consumers. Now to develop local products is very easy and can be reached by all levels of society. Manufacturers must have a present and unique spirit to pursue competition for products according to the development needs of consumers. Many rural communities are now plunging into online stores that provide online shopping convenience and there are providing local products that are difficult to find in regions or cities that have very good quality and have their own allure for consumers.

\section{Effect of price perception on trust.}

Online shopping the price is the main consideration because buyers do not know for sure about the quality of the goods. Do not let the expensive price happen and it turns out the quality of goods is not as expected. Online businesses need to give buyers the flexibility to perceive the prices associated with their expectations to get a quality product. Accurate information can increase price perception because buyers feel confident and trust in the existence of online sellers.

Endorsers encourage consumer confidence to be high because they take advantage of goods sold for consumption. Consumers are trying to find products that are used by vendors, then the seller needs to educate consumers about the benefits of products/services. Social media like Instagram is a tool to convey information to human users of social media. Shopping online is easy but must be careful with the risks faced because they do not know the real goods.

Many online sellers give a guarantee that if the goods arrive at the buyer is damaged, then they must provide information to the seller so that the same item will be replaced. For that, online sellers need cooperation with producers, so that many have the type of goods needed by humans. Manufacturers need to be suppliers of online shopping in order to be recorded and to facilitate transactions with consumers. In online shopping will be cheaper because these transaction activities can shorten the distribution channel, so it can be said that online shopping is efficient and effective for people who have busy activities every day.

The results of this study indicate that price perceptions have a positive and tangible influence on both trustworthiness and purchasing decisions in online shopping through Instagram. This means that consumer confidence in price information is very high, so they can decide to buy goods or services. Prices can trigger people to buy goods because they can already measure their own purchasing power. For this reason, a pricing policy in the form of discounts, free shipping, and guarantees on goods will be an important consideration for consumers to buy the goods. 


\section{Information quality influence buying decision.}

Information quality influences baying decisions on Instagram social media, but the information presented can be trusted by consumers. The quality of information is said to be the consumer's perception of the quality of information about products or services available on a website (Park and Kim, 2003)[10]. Information should be useful and relevant for predicting the quality and benefits of goods or services. To satisfy online consumers' needs for information, information about goods and services must be up-to-date in order to help online shoppers make decisions consistently and easily understood by consumers. Goods information about online shopping includes information on product attributes, recommendations of consumers who have made transactions and evaluating monitoring reports from consumers who have shopped online.

The information aspect is crucial for making an ad on the internet because it does not yet know the character of the consumer. Even marketers try their best to make advertisements on the internet that have high entertainment value, in order to attract the attention of consumers. The information presented on online shopping is mainly like information about goods and services available in online stores. The results of research from Gabriel Sperandio Milan et.al (2015)[26] state that information quality has a positive and direct influence on consumer purchasing decisions on online purchasing websites. Available information about products sold on the website and accessibility of information can increase actual purchases.

The results of this study are consistent with research by Adityo and Khasanah (2015)[27] about the information quality on online purchasing decisions on the Kaskus Site. The result is that information quality has a positive and significant impact on purchasing decisions. This means that the information quality can help consumers shop online to find goods from virtual stores that are provided by online businesses in full. Buying decisions will occur if the information can be trusted and easily accessed and easily connected through WhatsApp listed in the information.

\section{Celebrity endorsers influence buying decisions.}

The online business world is currently developing very rapidly and competing to attract potential customers following the intended target market. Using a famous artist that is one form of promotion carried out by online business entrepreneurs, especially those engaged in the field of Fashion today is as a Celebrity Endorser. Celebrity Endorser can be a consideration for consumers to make purchasing decisions online shopping through Instagram. The endorser is an appropriate choice and meets the criteria including trustworthiness, physical attractiveness, expertise, similarity, and respect because it determines the success of the endorser in influencing consumers to make a purchasing decision.

The results of the study of M. Vijaya Kumar and M. Ramakrishnan (2016)[28] said that a positive and significant effect on consumer purchases that support celebrities includes knowledge, popularity and good personality of the endorser. The majority of respondents buy products because celebrities for that producers must continue to use celebrities as a promotional tool to inform consumers about the products offered. Aysegul et al., (2014)[29], found that celebrity endorsers have a positive relationship with purchasing decisions. It means that endorsers are needed in conducting promotions, especially online sellers, because as an encouragement so that buyers feel their needs are met. A female consumer is easily attracted to an endorser especially that artist, as her idol, so the items used, she wants to use the same items. Now there is a tendency for women to shop more online if there are advertisements for discounts they are more interested in shopping for goods online. 
Consumer advocates are now needed by online businesses because those who have already had transactions can be used to convey information on online shopping, that how to pay is easy, quality goods and goods arrive at buyers quickly according to orders. An ordinary buyer can help online business, to tell other friends to shop through Instagram because a lot of goods are sold at fantastic discounts, so they can get goods at low prices and quality as expectations. Information and price aspects will give impetus to consumers, but all can be trusted by buyers.

\section{Effect of price perception on buying decisions.}

The price component is very sensitive for consumers because to buy an item is always seen how much the price of the item. For that, online businesses try to give price discounts, bonuses by buying 2 get 1 free, to trigger a purchase. Consumer purchasing decisions are positively and significantly influenced by price perceptions so the hypothesis can be accepted meaning consumer purchasing decisions will increase if price perceptions are trusted by consumers. The results of this study support the research of Owusu Alfred (2013)[30]. Whereas Ya-Hui Wang and Li-Yan Chen with research findings indicate that price perception has a positive and significant influence on purchase intention. Every human who shop online always pay attention to the price offered by the seller and at the same time measure the purchasing power of consumers[31].

Purchasing products online that price perception of the product becomes the mind of the consumer. Consumers know that products sold online offer cheap prices, even though when making a purchase transaction they still weigh the price that applies to a product according to its quality. With accurate information about prices, consumers still weigh the risks that will occur when buying online. Access related to prices needs to be known by consumers because it will be used as a guide in purchasing decisions.

Success in business lies in the seller offering goods that fit his needs and meeting expectations regarding quality and technical safe delivery. Perception of the price is not only the real price of an item but includes discounts, bonuses, and procedures for buying it is also perceived by consumers. Price is motivated to want to feel the benefits and value of the product purchased, so consumers are sensitive to the goods offered. Consumers expect cheaper and more economical prices and the opportunity to get prizes from the purchase of goods online. Consumer social status also influences the decision to buy that people who shop online are positioned as rich people, because they pay online and receive goods at home.

\section{Trust influences on baying decision.}

There is a positive and significant influence of trust in purchasing decisions on social media users including those using Instagram. The element of information, celebrity endorser and price perception and even other elements, it takes the trust of consumers to make a buying decision. The main aspect that influences purchasing decisions is the trust of the community. According to Royan (2002: 34)[12], trust is built up because there is hope from other parties that will act according to the needs and desires of consumers. Someone has been trusted by the other party so they must be sure with the hope that will be fulfilled and there will be no disappointment. The results of research from Lau and Lee (1999) [16] say that trust in the product is the willingness of consumers to trust the product with all risks, because of the expectations promised by the product in providing positive results for consumers.

Trust is a source of consumer expectations will be fulfilled product promises and information needed by humans. If the expectation of online buyers is not fulfilled, then the trust will be reduced and even disappear and do not want to shop online. When consumer confidence is 
lost, it is difficult for online sellers to regrow so that they buy as before. Consumer confidence in information, goods that influence purchasing decisions, because consumers have a more vigilant attitude to products that are not yet known even the quality is not clear. Trust in information about prices and products can be realized if it meets the expectations and needs of consumers, so consumers will be satisfied with what is offered in online shopping.

Trust can arise if consumers have felt satisfaction, for example, using products sold in online stores. Even more, trust if the goods sold offline are known to be of good quality, so when they are sold online and prices are cheaper and easier consumers will buy online. Consumers feel comfortable and trust because of a product, it will not be easy to leave the product. The results of this study support research from Adityo and Khasanah (2015)[27] researching the effect of trust on online purchasing decisions on the Kaskus website ". The results of the study that trust has a positive and significant effect on purchasing decisions.

\section{CONCLUSION}

The results of the analysis of each variable and the hypothesis test can be concluded as follows:

1. The information quality can be used as a basis for consideration of consumer confidence in the process of making online buying decisions. Online business people always prepare information that is accurate and easy to read by consumers who shop online, especially via Instagram. The existence of information technology that is developing rapidly, then humans are increasingly innovative in running their businesses. Providing news through Instagram about goods to be sold must be done because almost all residents in Indonesia are social media literate. The description of the products/services that will be sold online, it needs to be displayed well and interestingly so that consumers who shop online immediately decide to make a purchase.

2. Consumer confidence in the presence of celebrity endorsers is very helpful in online business because endorsers play a role in advertising these products. Endorsers can have many clients promoting products, so consumers will know more about the latest products. Online businesses will have a wealth of information and knowledge related to consumer needs. Celebrity endorsers are expected to be the spokesperson for the product/service, so that it can quickly cling to the minds of consumers, so consumers want to buy products that they need. Celebrities can be used as an appropriate tool for representing the intended market segment. Consumers remember endorsers in carrying out activities related to product promotion will accelerate to make decisions about buying products offered in online shopping.

3. Price perception will change consumer confidence because as a basis for determining the desired purchase. For this reason, price perception is the reason why consumers decide to buy online. See prices that can be categorized as low, high and fair that can be felt even the experience that is felt when using a product by consumers. The reference price owned by consumers is the price that is considered appropriate, the price set for a product, even considered as a low market price and can be said to be high. Generally, the reference price acts as a guideline for evaluating whether the price set is acceptable or not by consumers.

4. Complete and trustworthy information will be an attraction for people who like shopping online. Submission of information through social media can be done to influence the community. Information about a product through social media that is Instagram has a purpose so that people know and are interested in using the product. Valid information from a trusted source can be useful in assessing any opinions expressed on social media by the information needed by consumers. The quality of 
information presented in the diagram can affect consumers to decide to buy a particular product. But it is not the only factor that influences purchasing decisions.

5. Some consumers say that by using the role of endorser, the product will sell well, but it is not always true because many aspects contribute to the purchasing decision. It can also be goods that were previously traditionally sold, then sold online, so many people will buy it because it will be cheap and easy to get the item. The role of the endorser for new goods is very effective for introducing goods because consumers know better through social media. Instagram makes online businesses enthusiastic because they can display the endorser in its entirety so that it can be read and watched carefully so that it is not wrong in deciding to buy it.

6. The rise of online businesses due to attractive offers such as discounts, free shipping and warranty of goods until the destination in good condition. The general public has a price perception that online shopping is cheaper and can be easy. Why prices are cheaper because distribution channels are shorter, Instagram's role connecting the two parties. The buyer is not difficult anymore, must leave the house while sleeping while holding the cellphone, can make transactions online wherever we need.

7. Building consumer confidence takes a long time, but with the help of Instagram people can buy things from home. The process of human trust in products has a strong carrying capacity to make important decisions in life. Deciding to buy products online many factors that influence, but must consider the most important aspects to convince yourself, in order to easily achieve life goals. The element of risk must be taken into consideration because between the seller and the buyer do not do face to face directly, then we are always alert to the possibility of the worst disaster such as the goods not being sent. Be careful when making an online purchase, you must understand the characteristics of people who want to cheat by offering products online.

\section{References}

Kotler dan Keller, Marketing Management, Global. England: Pearson Education Limited, 2018.

Dharmmesta Basu Swasta dan Irawan, Manajemen Pemasaran Modern. Yogyakarta: Liberty, 2008.

Sudaryono, Manajemen Pemasaran. Yogyakarta: Andi, 2016.

P. Kotler, Marketing Management, 10th ed. New Jersey: Pearson Prentice Hall, 2007.

Sofjan Assauri, Manajemen Pemasaran. Jakarta: Raja Grafindo Persada, 2014.

B. Alma, Manajemen Pemasaran dan Pemasaran Jasa. Bandung: CV. Alfabeta, 2014.

Boone dan Kurtz, Contemporary Business, 11th ed. Jakarta: Salemba Empat, 2017.

C. Liu and K. P. Arnett, "Exploring the factors associated with Web site success in the context of electronic commerce," Inf. Manag., vol. 38, no. 1, pp. 23-33, 2000.

S. J. Barnes and R. Vidgen, "Measuring web site quality improvements: A case study of the forum on strategic management knowledge exchange," Ind. Manag. Data Syst., vol. 103, no. 5-6, pp. 297-309, 2003.

C. H. Park and Y. G. Kim, "A framework of dynamic CRM: Linking marketing with information strategy," Bus. Process Manag. J., vol. 9, no. 5, pp. 652-671, 2003.

T. A. Shimp, Integrated Marketing Comunication in Advertising and Promotion. Singapore: Thomson, South Western, 2007.

F. M. Royan, Marketing Celebrity. Jakarta: PT Elex Media Komputindo, 2005.

Handi Chandra, Marketing untuk orang awam. Palembang: Maxikom, 2008.

L. L. Schiffman, L.G., \& Kanuk, Consumer Behaviour, 10th ed. New Jersey: Pearson Prentice Hall, 2010.

A. Cockrill and M. M. H. Goode, "Perceived price fairness and price decay in the DVD market," J. Prod. Brand Manag., vol. 19, no. 5, pp. 367-374, 2010. 
G. T. Lau and S. H. Lee, "Consumers' Trust in a Brand and the Link to Brand Loyalty," J. Mark. Manag., vol. 4, no. 4, pp. 341-370, 1999.

Lim. et.al., Sustainble Marketing Enterprise In Asia. Singapura: Prentice Hall, 2001.

Halik at.al., "Customer Trust as Intervening Variable of the Influence of Marketing Mix, Service Quality and Religious customer commitment in Sharia Bank Public," pp. 611-623, 2017.

P. dan G. A. Kotler, Principle Of Marketing, 15th ed. New Jersey: Pearson Prentice Hall, 2014.

Machfoedz, Pengantar pemasaran modern. Yogyakarta: Akademi Manajemen Pemasaran YPKPN, 2013.

A. P. Mahkota, I. Suyadi, and Riyadi, "PENGARUH KEPERCAYAAN DAN KENYAMANAN TERHADAP KEPUTUSAN PEMBELIAN ONLINE (Studi Pada Pelanggan Website Ride Inc)," J. Adm. Bisnis, vol. 8, no. 2, 2014.

F. N. Kerlinger, Foundations of behavior research, Therd. Yogyakarta: Gajah Mada University, 1990.

K. V. and D. G. . Aaker A, Marketing Research. New York: John Wiley \& Sons Inc., 2001.

Sugiyono, Metode Penelitian Bisnis. Bandung: Alfabeta, 2010.

I. Ghozali, Model persamaan struktural konsep \& aplikasi, 8th ed. Semarang: penerbit Universitas Diponegoro, 2017.

G. S. Milan, S. Bebber, D. De Toni, and L. Eberle, "Information Quality, Distrust and Perceived Risk as Antecedents of Purchase Intention in the Online Purchase Context," J. Manag. Inf. Syst. E-commerce, no. June 2016, 2015.

Benito Aditiya, "Analisis Pengaruh Kepercayaan, Kemudahan, dan Kualitas informasi Terhadap Keputusan Pembelian Secara Online di KASKUS," 2002.

M. V. Kumar and M. Ramakrishnan, "Role of Celebrity Endorser on the Purchase Decision of the Consumers," Asian J. Res. Soc. Sci. Humanit., vol. 6, no. 6, p. 1029, 2016.

I. Review, M. Vol, A. E. Sertoglu, O. Catli, and S. Korkmaz, "Examining the Effect of Endorser Credibility on the Consumers' Buying Intentions: An Empirical Study in Turkey," Int. Rev. Manag. Mark., vol. 4, no. 1, pp. 66-77, 2014.

O. Alfred, "Influences of Price And Quality On Consumer Purchase Of Mobile Phone In The Kumasi Metropolis In Ghana A Comparative Study," Eur. J. Bus. Manag., vol. 5, no. 1, pp. 179-199, 2013.

Y.-H. Wang and C. Li-Yan, "An Empirical Study of the Effect of Perceived Price on Purchase Intention Evidence from Low-Cost Carriers," Int. J. Bus. Soc. Sci., vol. 7, no. 4, p. 41170, 2016. 